DOI: 10.17707/AgricultForest.65.1.08

\author{
Zeina EL SEBAALY*, Falah ASSADI, \\ Youssef Najib SASSINE, Nidal SHABAN ${ }^{1}$
}

\title{
SUBSTRATE TYPES EFFECT ON NUTRITIONAL COMPOSITION OF BUTTON MUSHROOM (AGARICUS BISPORUS)
}

\begin{abstract}
SUMMARY
Button mushroom (Agaricus bisporus) has been recognized as a fair substitute for meat and is the most intensively cultivated mushroom worldwide. The nutritional value of the mushroom is one of the main factors determining its quality. The current study investigated the variation in nutritional composition of button mushroom as affected by substrate type. Three locally composted wastes were used; chic: deep litter chicken manure, ban: banana wastes (leaves and pseudo-stems) and win: winery wastes (grape marc). Each type of compost was mixed separately with horse manure compost (hors) in different ratios (30\%, $50 \%, 70 \%$ and $100 \%$ ) on volume basis. Control substrate consisted of $100 \%$ horse manure compost.

Results showed that in the mixture hors-win: 30-70 water, fat, $\mathrm{Mg}, \mathrm{Fe}, \mathrm{Cu}$, $\mathrm{Zn}$, Na and Ca contents were reduced, while ash and $\mathrm{K}$ contents were increased. There was a peak of water (90\%), proteins $(5.2 \%)$, Fe $(21.9 \mathrm{mg} / \mathrm{kg})$, Cu (18.6mg/kg), Zn (10.2mg/kg), Na (74.5mg/kg), K (2mg/kg) and Ca $(65.8 \mathrm{mg} / \mathrm{kg})$ contents in mushrooms picked from hors-chic: 0-100. Moreover, growing the mushroom on composted banana wastes (hors-ban: 0-100) produced fruits with the lowest protein (2.9\%), fat (0.01\%), Mg (147.5mg/kg), Na $(64.8 \mathrm{mg} / \mathrm{kg}), \mathrm{K}$ $(1.4 \mathrm{mg} / \mathrm{kg})$ and $\mathrm{Ca}(55.8 \mathrm{mg} / \mathrm{kg})$ contents and the highest ash content $(2 \%)$. It seemed that the total use of chicken manure compost allowed the production of mushrooms with the closest nutritional composition to those of the traditional compost.
\end{abstract}

Keywords: Button mushroom, nutritional value, substrate.

\section{INTRODUCTION}

Mushrooms are very popular and valuable food items in modern dietary regimes because of their nutritional value (Tshinyangu, 1996). Agaricus bisporus mushrooms are often considered to provide a substitute for meat with a comparable nutritional value to many vegetables. The authors assume that they both add flavor and are a valuable food which can make a valuable addition to

\footnotetext{
${ }^{1}$ Zeina El Sebaaly*(corresponding author: zeinasebaaly1@hotmail.com), Nidal Shaban, University of Forestry, 10 Kliment Ohridski blvd, BG1797 Sofia, BULGARIA; Falah Assadi, Youssef Najib Sassine, Lebanese University, Faculty of Agricultural Engineering and Veterinary Medicine, Dep. Horticulture, Beirut, LEBANON

Paper presented at the $9^{\text {th }}$ International Scientific Agricultural Symposium "AGROSYM 2018".

Notes: The authors declare that they have no conflicts of interest. Authorship Form signed online.
} 
the often unbalanced diets of people in developing countries (Chang and Miles, 2004). Protein is an important constituent of mushrooms dry matter (Chang and Buswell, 1996), carbohydrate represent the bulk of their fruiting bodies and their fat content is very low (Wani et al., 2010). Given the crucial role that minerals play in the biological process and metabolism and their therapeutic use in dietary supplements, foods are often tested for nutrient minerals in relation to specific health benefits (Tomkins, 2002). Agaricus bisporus (button mushroom) has an especially high content of phosphorus, sodium and potassium (Bakowski et al., 1986) followed by $\mathrm{Ca}, \mathrm{Mg}$, Na, Fe and Zn (Guillamón et al., 2010; Falandysz and Borovička, 2013). It is also an excellent source of several essential amino acids and vitamins (B2, niacin and folate) (Manzi et al., 2001).

The Agaricus mushroom is a heterotrophic fungus growing naturally on a partially degraded organic substrate. It requires for its nutrition and subsequent metabolism, carbon compounds that have already been produced by green plants (Wood and Fermor, 1985). Traditionally, the mushroom is grown on composted horse manure and wheat straw (Chang and Miles, 2004). Compost is normally supplemented by adding proteins and lipids additives (Weil et al., 2004) or by ingredients with high levels of vegetable proteins (Zied et al., 2011). However, according to Arce-Cervantez et al. (2015) the development of inexpensive, readily available alternative supplements is a necessity to reduce the costs of mushroom production.

In Lebanon, Agaricus bisporus is highly demanded however the development of mushroom sector is highly dependent on the availability of substrates at the local level (Karam et al., 2010). Due to the scarcity of horse manure, alternative substrates based partially or totally on chicken manure and winery wastes were reported by Sebaaly et al. (2018a) and Sebaaly et al. (2018b) as being efficient for producing good yields of button mushroom. However, since the efficient use of local agricultural wastes is quite evident in order to optimize not only yield but also quality of button mushroom produced. Therefore, the study investigated the nutritional composition of mushrooms produced from substrates containing local winery wastes, banana wastes and chicken manure in order to evaluate the substrate effect on the various mushroom components.

\section{MATERIAL AND METHODS}

Eleven substrates of different properties (Table 1) were formed by three types of local agricultural wastes that were used alone (100\%) or mixed with the traditional compost (based on horse manure and wheat straw) in various proportions ( $30 \%, 50 \%$ or $70 \%$ ) on a volume basis. The nutritional composition of $A$. bisporus mushrooms of the strain A15 was evaluated and compared among the various substrates and a control substrate consisting of traditional compost.

Ten representative samples of mushrooms harvested from each substrate type were dried in an oven at $70^{\circ} \mathrm{C}$ for 12 hours and made into fine powder before being analyzed for composition. Complete mushrooms (stipe and cap) were 
dried. Thereafter, moisture, proteins, carbohydrates, fat, crude fibers and ash contents using standard method of analysis (AOAC, 1995).

For the determination of mineral elements ( $\mathrm{Ca}, \mathrm{K}, \mathrm{Mg}$ and $\mathrm{Na}$ ) and $\mathrm{Fe}$, dried mushroom samples were digested in concentrated $\mathrm{HNO}_{3}$. Then, elements were quantified by atomic emission spectrometry (Matila and Konko, 2001). All the elements were analyzed in triplicate.

Table 1: Compositional characteristics of growing substrates

\begin{tabular}{lcccccc}
\hline $\begin{array}{l}\text { Substrate } \\
\text { mixture }\end{array}$ & $\begin{array}{c}\text { Moisture } \\
\text { content (\%) }\end{array}$ & $\begin{array}{c}\text { Organic } \\
\text { matter (\%d.w.) }\end{array}$ & $\begin{array}{c}\text { Total } \\
\text { nitrogen } \\
\text { (\%d.w.) }\end{array}$ & $\begin{array}{c}\text { Carbon } \\
\text { (\%d.w.) }\end{array}$ & C:N & pH \\
\hline S1 & 54.8 & 65.5 & 1.9 & 34.2 & $18: 1$ & 5.9 \\
S2 & 63.4 & 69.4 & 1.9 & 36.1 & $19: 1$ & 6.1 \\
S3 & 58.7 & 75.8 & 1.8 & 34.2 & $19: 1$ & 6.4 \\
S4 & 62.1 & 81.7 & 2 & 42 & $21: 1$ & 6.5 \\
S5 & 55.1 & 64.8 & 1.9 & 34.2 & $18: 1$ & 5.9 \\
S6 & 58.5 & 61.9 & 2 & 36 & $18: 1$ & 5.6 \\
S7 & 63.1 & 56.2 & 2.1 & 35.7 & $17: 1$ & 5.6 \\
S8 & 62.7 & 54.7 & 2.3 & 39.1 & $17: 1$ & 5.1 \\
S9 & 63.9 & 70.2 & 1.9 & 37.1 & $20: 1$ & 6.2 \\
S10 & 65.1 & 73.8 & 1.8 & 40.4 & $22: 1$ & 6.3 \\
S11 & 68.2 & 78.5 & 1.8 & 43.2 & $24: 1$ & 6.7 \\
S12 & 72.4 & 80.9 & 1.6 & 41.6 & $26: 1$ & 6.8 \\
\hline
\end{tabular}

S1: control, S2: Hors-win: 70-30, S3: Hors-win:50-50, S4: Hors-win:30-70, S5: Hors-chic:70-30, S6: Hors-chic:50-50, S7: Hors-chic:30-70, S8: Hors-chic:0-100, S9: Hors-ban:70-30, S10: Horsban:50-50, S11: Hors-ban:30-70, S12: Hors-ban:0-100

\section{Data analysis}

Data analysis was performed using SPSS 23. ANOVA and Duncan tests were applied with a $\mathrm{P}_{\text {value }}<0.05$ as a significant difference between treatments.

\section{RESULTS AND DISCUSSION}

Results of ANOVA test showed that the effect of substrate type was statistically significant $\left(\mathrm{P}_{\text {value }}<0.05\right)$ on water, proteins, carbohydrates, fat, ash, magnesium, iron, sodium, potassium and calcium contents, while it was not significant on crude fibers content in mushrooms.

Compositional characteristics varied among mushrooms produced by the different compost formulations (Figure 1). In general, mushroom moisture content was the highest in chicken manure compost (hors-ban: 0-100) (90.7 \%) and the lowest in the substrates hors-win: 30-70 and hors-ban: 50-50 (around $85.5 \%$ ). Mushroom moisture content in control was higher compared to treatments containing horse manure mixed with banana or winery wastes in all ratios except hors-ban: 30-70 (88.2 \%) and hors-win: 50-50 (88.6 \%), while it was lower compared to treatments containing horse manure mixed with chicken manure in all ratios except hors-chic: 50-50 (88.1\%). 

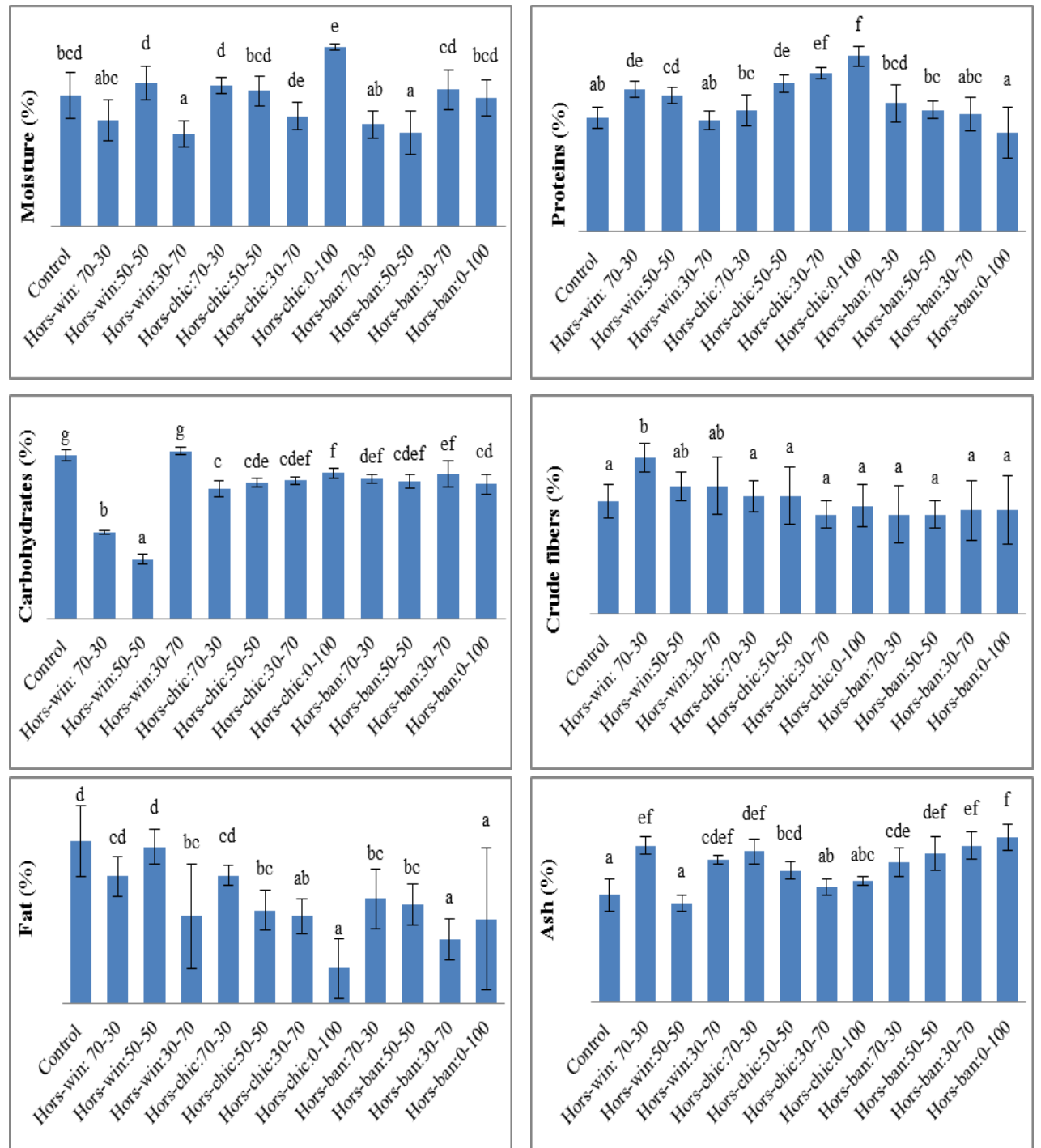

Figure 1: Effect of substrate type on moisture, proteins, carbohydrates, crude fibers, fat and ash contents of mushrooms (Means followed by the same letter are not significantly different according to Duncan's significant difference $\mathrm{P}<0.05$ ).

In addition, mushroom protein content was ameliorated by the presence of chicken manure with various ratios in the substrate $(3.6 \%, 4.4 \%$, and $4.7 \%$ in hors-chic: 70-30, hors-chic: 50-50 and hors-chic: 30-70 respectively) as well as by the presence of winery wastes in proportions up to $50 \%(4.2 \%$ and $4.0 \%$ in hors-win: 70-30 and hors-win: 50-50 respectively) compared to control (3.4\%). It was the highest in chicken manure compost (hors-chic: $0-100$ ) with $5.2 \%$ and the lowest in banana compost (hors-ban: 0-100) with $2.9 \%$. Carbohydrates content was generally reduced in all treatments compared to control except in the 
treatment hors-win: 30-70 where values were comparable (8.5 \% in hors-win: 3070 compared to $8.3 \%$ in control). Moreover, mushrooms produced in substrates containing winery wastes were the richest in crude fibers compared to all other substrates including control.

Mushroom fat content decreased in all treatments compared to control except in hors-win: 50-50 and it was the lowest in substrates based totally on chicken manure and banana wastes (0.02 \% and 0.01\% in hors-chic: 0-100 and hors-ban: 0-100 respectively). Ash content was the lowest in hors-ban: 50-50 (1.2 $\%)$ and control (1.3\%). It was slightly higher in substrates containing more than $50 \%$ chicken manure compost (1.4\% and $1.5 \%$ in hors-chic: $30-70$ and horschic: 0-100 respectively), while it was significantly improved in all remaining substrates.

Furthermore, in comparison with control, mushroom sodium content was gradually reduced when horse manure was mixed with increasing proportions of winery or banana wastes, while it was gradually increased when horse manure was mixed with increasing proportions of chicken manure. Magnesium content did not significantly differ among all treatments and control. In addition, mushroom iron content was the highest in substrates containing chicken manure in all proportions and calcium content was the highest in hors-chic: 50-50 and hors-chic: 30-70. Both elements were the lowest in substrates containing more than $50 \%$ banana wastes.

Finally, compared to control, mushroom potassium content was significantly lower in substrates with more than $30 \%$ banana wastes, significantly higher in those containing more than 50 \% chicken manure, almost equal in mushrooms of hors-ban: $70-30$ and slightly higher in remaining substrates (Table 2).

Table 2: Effect of substrate type on mushroom mineral composition

\begin{tabular}{lccccc}
\hline & $\begin{array}{c}\mathbf{N a} \\
(\mathrm{mg} / \mathrm{kg})\end{array}$ & $\begin{array}{c}\mathbf{M g} \\
(\mathrm{mg} / \mathrm{kg})\end{array}$ & $\begin{array}{c}\mathbf{K} \\
(\mathrm{mg} / \mathrm{kg})\end{array}$ & $\begin{array}{c}\mathbf{C a} \\
(\mathrm{mg} / \mathrm{kg})\end{array}$ & $\begin{array}{c}\mathbf{F e} \\
(\mathrm{mg} / \mathrm{kg})\end{array}$ \\
\hline S1 & $72.9^{\mathrm{cd}} \pm 1.2$ & $160.5^{\mathrm{d}} \pm 2.5$ & $1.6^{\mathrm{ab}} \pm 0.1$ & $62.5^{\mathrm{cd}} \pm 1.2$ & $20.4^{\mathrm{de}} \pm 1.0$ \\
S2 & $70.2^{\mathrm{b}} \pm 1.3$ & $159.7^{\mathrm{d}} \pm 1.7$ & $1.7^{\mathrm{abc}} \pm 0.2$ & $62.1^{\mathrm{cd}} \pm 1.5$ & $19.5^{\mathrm{cd}} \pm 1.0$ \\
S3 & $69.5^{\mathrm{b}} \pm 0.6$ & $157.5^{\mathrm{cd}} \pm 1.3$ & $1.9^{\mathrm{bc}} \pm 0.2$ & $60.2^{\mathrm{bc}} \pm 1.8$ & $19.0^{\mathrm{bcd}} \pm 1.7$ \\
S4 & $65.5^{\mathrm{a}} \pm 1.4$ & $150.5^{\mathrm{a}} \pm 1.5$ & $1.9^{\mathrm{bc}} \pm 0.2$ & $59.1^{\mathrm{b}} \pm 2.0$ & $19.2^{\mathrm{bcd}} \pm 0.9$ \\
S5 & $73.3^{\mathrm{cd}} \pm 1.5$ & $159.8^{\mathrm{d}} \pm 2.4$ & $1.8^{\mathrm{abc}} \pm 0.4$ & $62.9^{\mathrm{cd}} \pm 1.1$ & $20.8^{\mathrm{de}} \pm 0.9$ \\
S6 & $73.2^{\mathrm{cd}} \pm 0.7$ & $159.4^{\mathrm{d}} \pm 1.6$ & $1.7^{\mathrm{abc}} \pm 0.1$ & $63.3^{\mathrm{de}} \pm 1.9$ & $21.4^{\mathrm{e}} \pm 0.8$ \\
S7 & $74.2^{\mathrm{d}} \pm 0.8$ & $155.1^{\mathrm{bc}} \pm 2.1$ & $2.3^{\mathrm{d}} \pm 0.3$ & $64.7^{\mathrm{de}} \pm 0.7$ & $21.8^{\mathrm{e}} \pm 1.2$ \\
S8 & $74.5^{\mathrm{d}} \pm 1.3$ & $158.3^{\mathrm{cd}} \pm 1.6$ & $2.0^{\mathrm{cd}} \pm 0.1$ & $65.8^{\mathrm{c}} \pm 0.7$ & $27.9^{\mathrm{e}} \pm 1.0$ \\
S9 & $71.2^{\mathrm{bc}} \pm 1.7$ & $155.5^{\mathrm{bc}} \pm 2.4$ & $1.6^{\mathrm{ab}} \pm 0.2$ & $60.4^{\mathrm{bc}} \pm 2.1$ & $19.5^{\mathrm{cd}} \pm 0.9$ \\
S10 & $70.1^{\mathrm{b}} \pm 2.3$ & $153.1^{\mathrm{ab}} \pm 0.8$ & $1.5^{\mathrm{a}} \pm 0.2$ & $60.0^{\mathrm{bc}} \pm 2.9$ & $18.1^{\mathrm{abc}} \pm 0.5$ \\
S11 & $65.9^{\mathrm{a}} \pm 1.0$ & $160.8^{\mathrm{d}} \pm 1.5$ & $1.4^{\mathrm{a}} \pm 0.2$ & $57.8^{\mathrm{ab}} \pm 1.3$ & $17.5^{\mathrm{ab}} \pm 0.5$ \\
S12 & $64.8^{\mathrm{a}} \pm 4.3$ & $161.2^{\mathrm{d}} \pm 3.0$ & $1.4^{\mathrm{a}} \pm 0.3$ & $55.8^{\mathrm{a}} \pm 5.7$ & $16.6^{\mathrm{a}} \pm 3.0$ \\
\hline
\end{tabular}

S1: control, S2: Hors-win: 70-30, S3: Hors-win:50-50, S4: Hors-win:30-70, S5: Hors-chic:70-30, S6: Hors-chic:50-50, S7: Hors-chic:30-70, S8: Hors-chic:0-100, S9: Hors-ban:70-30, S10: Horsban:50-50, S11: Hors-ban:30-70, S12: Hors-ban:0-100 
The study reflected the effect of substrate type on mushroom composition. Supplementing horse manure with banana or winery wastes with up to $50 \%$ (on volume basis) would extend the mushroom shelf-life since in those substrates moisture content was reduced. On the contrary, the addition of chicken manure induced an average moisture content of $89.2 \%$ which would affect negatively the mushroom shelf-life. In products with such high water content (>85\%) and with no conventional cuticle as mushrooms, evaporation and consequently loss of weight usually have detrimental effect on shelf-life (Hammond and Nichols, 1975). Mushrooms secrete enzymes to digest surrounding foodstuff to get nutrients from organic matter contained in compost. In other terms, they are grown by bioconversion of agricultural wastes into edible food (Goyal et al., 2006). As a result, their nutritional value largely depends on the chemical composition of the compost (Tshinyangu, 1996; Gothwal et al., 2012). It was observed that the lowest and highest mushroom protein contents were obtained respectively with the substrates with lowest (hors-ban: 0-100 with $1.6 \% \mathrm{~N}$ ) and highest (hors-chic: 0-100 with $2.3 \% \mathrm{~N}$ ) nitrogen contents. Even with the same species, values obtained values of protein content were lower than those reported by Sadiq et al. (2008): $11.01 \%$, Muszyńska et al. (2011): 25\%, Mohiuddin et al. (2015): 17.7\%-24.7\% and Ahlavat et al. (2016): $29.14 \%$ in different growing substrates, while they were in the range indicated by Chang and Miles (2004): 3.5 to $4 \%$.

In general, the total substitution of the traditional compost or its supplementation by the various types of tested wastes has allowed the production of mushrooms with qualitative attributes highly demanded by consumers of healthy food such as low fat and carbohydrates contents and good composition in dietary fibers which play a key role in healthy properties of mushrooms (Cheung, 2009). Furthermore, mushrooms are known to be an excellent accumulator of minerals from the environment in which they grow (Atilda et al., 2017). The mineral composition of the button mushroom is undoubtedly affected by the composition of growth substrate (Bakowski et al., 1986) and is differently presented by various authors (Beelman and Edwards, 1989; Mattila and Konko, 2001; Vetter, 2003). It seemed that the utilization of chicken manure as a main substrate or as a supplement for the traditional compost has increased sodium, potassium, calcium and iron contents in fruits which is convenient for consumers with calcium deficiencies or anemia but is not suitable for consumers with blood pressure problems.

\section{CONCLUSIONS}

Mushrooms obtained in substrates where local wastes were implemented were of comparable composition to those obtained from the traditional horse manure-based compost. Results varied with the type of waste as well as with the ratio of each waste type in the substrate. The safe usage of chicken manure, winery and banana wastes were earlier reported on same or other mushroom 
species. Consequently, we recommend the implementation of such types of agricultural wastes in button mushroom production in Lebanon.

\section{REFERENCES}

Ahlavat O.P., Manikandan K. and Singh M. (2016). Proximate composition of different mushroom varieties and effect of UV light exposure on vitamin D content in Agaricus bisporus and Volvariella volvacea. Mushroom Research, 25(1): 1-8.

AOAC (1995). Official methods of analysis. In: Association of Analytical Chemists, 16th edn. Arlington.

Arce-Cervantes O., Saucedo-García M., Leal Lara H., Ramírez-Carrillo R.,Cruz-Sosa F. and Loera O. (2015). Alternative supplements for Agaricus bisporus production and the response on lignocellulolytic enzymes. Scientia Horticulturae 192: 375380.

Atilda F., Owaid M.N. and Shariati M.A. (2017). The Nutritional and Medical Benefits of Agaricusbisporus : A review. Journal of Microbiology, Biotechnology and Food Science, 7(3): 281-286.

Bakowski J., Kosson R. and Horbowicz M. (1986). Nutritional value of different species of mushrooms (Agaricus bisporus). 39(1): 111-121.

Beelman R.B. and Edwards C.G. (1989). Variability in the composition and nutritional value of the cultivated mushroom Agaricus bisporus. Mushroom News 37: 17-26.

Chang S.T. and Buswell J.A. (1996). Mushroom Nutriceuticals. World J. Microbiol. Biotechnol., 12: 473-476.

Chang S.T. and Miles P.G. (2004). MUSHROOMS. Cultivation, nutritional value, medicinal effect and environmental impact, eds., CRC. Florida, pp. 395.

Cheung P.C.K. (2009). Mushrooms as functional foods (ed P. C. K. Cheung), John Wiley \& Sons, Inc., Hoboken, NJ, USA.

Falandysz J. and Borovička J. (2013). Macro and trace mineral constituents and radionuclides in mushrooms: health benefits and risk. Applied Microbiology and Biotechnology, 97: 477-501.

Gothwal R., Gupta A., Kumar A., Sharma S. and Alappat B.J. (2012). Feasibility of dairy waste water (DWW) and distillery spent wash (DSW) effluents in increasing the yield potential of Pleurotus flabellatus (PF 1832) and Pleurotus sajor-caju (PS 1610) on bagasse. 3 Biotechnology, 2, 249-257. https://doi.org/10.1007/s13205012-0053-9.

Goyal R., Grewal R.B. and Goyal R.K. (2006). Nutritional attributes of Agaricus bisporus and Pleurotus sajor caju mushrooms. Nutrition and Health, 2006, Vol. 18, pp. 179-184.

Guillamón E., García-Lafuente A., Lozano M., D’Arrigo M., Rostagno M.A., Villares A. and Martínez J.A. (2010). Edible mushrooms: Role in the prevention of cardiovascular diseases. Fitoterapia, 81: 715-723.

Hammond J.B.W. and Nichols R. (1975). Changes in respiration and soluble carbohydrates during the post-harvest storage of mushrooms (Agaricus bisporus). J Sci Food Agric 26: 835-842.

Karam C., Sassine Y.N., Mounayar D. and Abdel-Menhem G. (2010). Prospective of local Oyster mushroom production in Lebanon. Journal of Applied Sciences Research, 6(12): 2139-2142.

Mattila P. and Konko K. (2001). Content of vitamins, mineral elements and some phenolic compounds in cultivated mushrooms. J. Agric. Food Chem, 49, 23432348. 
Manzi I., Aguzzi A. and Pizzoferrato L. (2001). Nutritional value of mushrooms widely consumed in Italy. Food Chem., 73: 321-325.

Mohiuddin K.M., Alam M., Arefin T. and Ahmed I. (2015). Assessment of nutritional composition and heavy metal content in some edible mushroom varieties collected from different areas of Bangladesh. Asian Journal of Medical and Biological Research, 1(3): 495-501.

Muszyńska B., Sułkowska-Ziaja K. and Ekiert H. (2011). Indole compounds in fruiting bodies of some edible Basidiomycota species. Food Chemistry, 125: 1306-1308.

Sadiq S., Bhatti H.N. and Hanif M.A. (2008). Studies on chemical composition and nutritive evaluation of wild edible mushrooms. Iran Journal of Chemistry and Chemical Engineering, 27(3): 151-154.

Sebaaly Z., Hayek P., Sassine Y.N., Kfoury L., Kattar S. and Chalhoub S. (2018a). Using locally available chicken manure as a substitute to horse manure in compost formulas for growing Agaricus bisporus in Lebanon. Paper presented at: International Symposium on culinary herbs and edible fungi, Istanbul, Turkey.

Sebaaly Z., Semaan H., Rizkallah J. and Sassine Y.N. (2018b). Investigating the potential use of composted grape marc in the production of Agaricus bisporus. Paper presented at: International Symposium on culinary herbs and edible fungi, Istanbul, Turkey.

Tomkins A. (2002). Nutrition, infection and immunity: public health implications. In Calder P.C., Filed C.J., Gill H.S., editors: Nutrition and Immune function. CABI Publishing, Wallingford, UK, 375-412.

Tshinyangu K.K. (1996). Effect of grass hay substrate on nutritional value of Pleurotus ostreatus var. Columbinus. Die Nahrung, 40: 79-83.

Vetter J. (2003). Chemical composition of fresh and conserved Agaricus bisporus mushroom. European Food Research and Technology 217: 10-12.

Wani A.B., Bodha R.H. and Wani A.H. (2010). Nutritional and medicinal importance of mushrooms. Journal of medicinal plant research 4(24): 1-7.

Weil D.A., Beelman R.B. and Beyer D.M. (2004). Effect of adding a micronutrient-rich supplement to compost on yield and quality of Agaricus bisporus. Science and Cultivation of edible and medicinal fungi. Rinker \& Royse (eds), Romaine, Keil. pp. 365-371.

Wood D.A. and Fermor T.R. (1985). Nutrition of Agaricus bisporus. In: Flegg P.B., Spencer D.M and Wood D.A., eds: The Biology and Technology of the cultivated mushroom. Glasshouse Crops Research Institute, Littlehampton, U.K., pp. 43-60.

Zied D.C., Savoie J.M. and Pardo-Giménez A. (2011). Soybean the main nitrogen source in cultivation substrate of edible and medicinal mushrooms, soybeans and nutrition, in: Prof. Hany El-Shemy (Ed.), ISBN: 978-953-307-536-5. InTech, Available from: http://www.Intechopen.com/books/soybean-andnutrition/soybean-the-main-nitrogen-source-in-cultivation-substrates-of-edibleandmedicinal-mushrooms 